\title{
PERIPHERAL CIRCULATING INSULIN-LIKE GROWTH FACTOR-I AND -II IN CATTLE
}

\author{
Judith Anna NiKOlić ${ }^{1 *}$, Olgica Nedić ${ }^{1}$, H. ŠAMANC ${ }^{2}$, S. AleKSiĆ ${ }^{3}$, B. MišČEVIĆ ${ }^{3}$ \\ and Margit KULCSÁR ${ }^{4}$ \\ ${ }^{1}$ INEP - Institute for the Application of Nuclear Energy, Banatska 31B, 11080 Zemun, \\ Yugoslavia; ${ }^{2}$ Faculty of Veterinary Medicine, University of Belgrade, Belgrade; \\ ${ }^{3}$ Institute for Animal Husbandry, Zemun, Yugoslavia; ${ }^{4}$ Faculty of Veterinary Science, \\ Szent István University, Budapest, Hungary
}

(Received November 11, 1999; accepted October 30, 2000)

\begin{abstract}
Interrelationships between circulating concentrations of the insulin-like growth factors (IGF-I and IGF-II) were investigated in 235 blood samples taken from 145 healthy beef or dairy calves, bulls and cows of different breeds and ages. Autoradiography of Western ligand blots indicated different IGF binding protein (IGFBP) profiles between sera from different categories of cattle. Each IGF radioimmunoassay was validated by determining the effects of IGFBPs, ligand and contraligand, as well as serial dilution and comparison with results obtained after molecular sieve chromatography in acid. In female cattle mean values for IGF-I varied from $5.1 \mathrm{nmol} / 1$ in postparturient Holstein cows to $18.5-20.5 \mathrm{nmol} / 1$ in growing beef heifers, while mean IGF-II concentrations ranged from $30.0 \mathrm{nmol} / 1$ in the cows to $14.7-15.7 \mathrm{nmol} / \mathrm{l}$ in the beef heifer calves. In male cattle mean serum IGF-I ranged widely from $8.2 \mathrm{nmol} / \mathrm{l}$ in 1-day-old Holstein calves to $67.4 \mathrm{nmol} / 1$ in 16-month-old Simmental-type bulls. Mean IGF-II concentrations decreased from $22.9 \mathrm{nmol} / \mathrm{l}$ in 1day-old Holstein bull calves to $11.9 \mathrm{nmol} / \mathrm{l}$ in 12 -month-old beef bulls. Thus, total molar IGF concentrations were fairly stable in female cattle $(24.7-35.1 \mathrm{nmol} / \mathrm{l})$ but extended from $27.3 \mathrm{nmol} / 1$ to $81.8 \mathrm{nmol} / 1$ in the male cattle. The tendency for a reciprocal relationship between serum concentrations of these growth factors was most obvious in the periparturient cows.
\end{abstract}

Key words: IGF-I, IGF-II, IGFBPs, radioimmunoassay, cattle

Insulin-like growth factor (IGF)-I (somatomedin-C) and its close relation IGF-II are single-chain polypeptides similar in structure to proinsulin. Besides local paracrine and autocrine actions on cells in various tissues, these mitogenic growth factors are present in the circulation from where they can regulate growth and metabolism of the whole organism (Stewart and Rotwein, 1996; Hossner et al., 1997; Hill et al., 1999). The anabolic effect of these peptides is mediated primarily via the IGF-I cell membrane rece ptor.

*E-mail: anikolic@inep.co.yu; Fax:+381 (11) 618-724 
Circulating IGFs are almost entirely bound to one of the specific binding proteins (IGFBPs) which attenuate or enhance IGF activity by multiple routes. This array probably reflects the endocrine action of the liver on other tissues, such as muscle and ovary (Gutiérrez et al., 1997). Hepatic synthesis of IGF-I and IGFBPs 1-4 can be stimulated or inhibited by other hormones including somat otropin, insulin, cortisol and the thyroid hormones, whereas synthesis of IGF-II appears to be constitutional. Due to the marked positive effect of somatotropin on IGF-I synthesis and secretion, this axis has been much studied in order to i ncrease the growth rate of beef cattle and the milk yield of dairy cows (e.g. Elsasser et al., 1989; McShane et al., 1989; Groenewegen et al., 1990). With a few exceptions (Skaar et al., 1991; Vega et al., 1991; Vicini et al., 1991; McGuire et al., 1992) IGF-II has been ignored, although IGF-II appears to be dominant du ring the fetal period and synthesis continues throughout life.

Quantitative determination of these peptides must be carried out with care due to the high affinity constants of the IGFBPs for IGF which may interfere with the specific antibody-ligand reaction in the assay. It is necessary to validate test procedures for each category of sample because the relative amounts and properties of the IGFBPs may differ in different circumstances (Bang, 1995).

Considering that assessment of IGF activity in animals is incomplete u nless both ligands are determined, this paper presents the results obtained for $\mathrm{s}$ erum IGF-I and IGF-II as well as the sum and ratio of their molar concentrations in healthy beef and dairy cattle of different ages. The complement of IGFBPs present was also evaluated by ligand blotting and autoradiogr aphy.

\section{Materials and methods}

\section{Quantitative analysis}

a) Purification. Bovine IGF was partially purified by subjecting bull serum $(5 \mathrm{ml})$ to molecular sieve chromatography on a calibrated column of Sephadex G-75 $(2.8 \times 32 \mathrm{~cm})$ using $1 \mathrm{M}$ acetic acid as the eluent. Fractions $(3.1 \mathrm{ml})$ containing the IGFs or IGF BPs were lyophilised. As required they were redissolved at $1 \mathrm{mg} / \mathrm{ml}$ in assay buffer $(0.05 \mathrm{M}$ sodium phosphate with $0.005 \mathrm{M}$ EDTA; $\mathrm{pH}$ 7.8).

b) Extraction. Aliquots of serum or plasma $(0.15 \mathrm{ml})$ were mixed and a llowed to stand with $0.85 \mathrm{ml}$ solution containing ethanol $(87.5 \%)$ and $2 \mathrm{M} \mathrm{HCl}$ $(12.5 \%$ ) for $30 \mathrm{~min}$ (Daughaday et al., 1982). After centrifugation for $30 \mathrm{~min}$ at $3000 \times \mathrm{g}$ the supernatant $(0.5 \mathrm{ml})$ was neutralised with $0.855 \mathrm{M}$ tris-(hydroxymethyl)aminomethane (TRIS) base and kept for at least $2 \mathrm{~h}$ at $-18{ }^{\circ} \mathrm{C}$ (Breier et al., 1991). Following further centrifugation, aliquots of the supernatant were a ssayed. Blank extracts of $0.15 \mathrm{ml}$ assay buffer were prepared in parallel. 
c) IGF-I assay. Human IGF-I (ICN Biomedicals Inc., Aurora, USA) 1abelled with ${ }^{125}$ I was used as the tracer and polyclonal rabbit antibodies to human IGF-I (Biogenesis, Poole, UK) as the reagent (Nikolić et al., 1996). Since bovine IGF-I has the same amino acid composition as human IGF-I ( Simmen, 1991), recombinant human IGF-I was used as the working standard (0.063-6.25 ng/tube). Cross-reactivity with IGF-II at 50\% inhibition of tracer binding was $0.054 \%$. R eproducibility was checked by including the reference preparation (WHO 87/518) in each test. The mean intraassay coefficients of variation (CV) for duplicate samples were routinely from $3 \%$ to $6 \%$. Interassay CVs were below $12 \%$.

d) IGF-II assay. The procedure described for human serum (Nikolić et al., 1998b) was used, employing recombinant human IGF-II ( ICN Biomedicals Inc., Aurora, USA) labelled with ${ }^{125} \mathrm{I}$ as the tracer and as the working standard (0.03$1.00 \mathrm{ng} /$ tube). The mouse monoclonal anti-rat IGF-II (Biogenesis, Poole, UK) was declared to be $100 \%$ cross-reactive with h-IGF-II. Under our assay conditions, cross reactivity with IGF-I at $50 \%$ inhibition of tracer binding was $0.4 \%$. Inhibition curves using h-IGF-II and purified bovine IGF fractions were compared for parallelism. Reproducibility was monitored with fresh extracts of human serum pools in each test (intraa ssay CVs $3-6 \%$; interassay CVs $<13 \%$ ).

e) Assay validation. The effect of the bovine IGFBP fractions on IGF-I and IGF-II determinations was examined. Possible interference from IGFBPs carried through the serum extraction procedure was checked by adding contral igand, which was not expected to alter the result, or ligand, which should increase the result by $100 \%$ of the amount added. Both serum extracts and IGF column fractions were progressively diluted and the relation between obtained and e xpected values determined. Serum stability was checked by determining IGF-I again after several years sto rage.

\section{Determination of IGFBP patterns}

Sodium dodecyl sulphate-polyacrylamide gel electrophoresis ( SDSPAGE) of serum samples was performed as described ( Hossenlopp et al., 1986; Nikolić et al., 1998a). Proteins were electrotransferred to nitrocellulose me mbranes $(0.45 \mu \mathrm{m}$, Schleicher and Schuell), followed by autoradiography after i ncubation with ${ }^{125}$ I-labelled IGF-I of specific activity approximately $36 \mathrm{MBq} / \mathrm{nmol}$. Protein bands were putatively identified according to the mobility of reference standards: bovine serum albumin (BSA, $66 \mathrm{kD})$, ovalbumin $(45 \mathrm{kD})$, glyceraldehyde-3-phosphate dehydrogenase (36 kD), carbonic anhydrase (29 kD), chymotrypsin $(24 \mathrm{kD}), \beta$-lactoglobulin $(18 \mathrm{kD})$ and ribonuclease $(14 \mathrm{kD})$.

\section{Animals and procedure}

Group 1 consisted of 44 Holstein-Friesian calves of both sexes born within three weeks in May and reared on a large dairy farm. Blood samples were taken 
NIKOLIĆ et al

by jugular puncture soon after birth before intake of colostrum and again at 4.5 months old when the calves were sent to the feedlot.

Group 2 contained calves, mainly of the Limousine and Charolais breeds (19 female, 14 male), kept with their dams and fed forage-based diets. A total of 55 samples was obtained from these beef cattle at 7 days, 6 months and 12 months of age over a period of 18 months in 1995-6. IGF-I was determined shortly after sampling and again in 1999, when IGF-II was measured.

Samples were also taken from 29 young bulls (6 Limousine and $23 \mathrm{Si} \mathrm{m}-$ mental-type domestic pied) reared under the same conditions (Group 3).

The fourth group consisted of 24 healthy periparturient Holstein cows (parity 2-5) kept tethered in the maternity parlour on another large dairy farm. Blood samples were obtained within the last week of pregnancy and during the first week post partum from each cow 4 to 10 days apart.

All blood samples were allowed to clot spontaneously at room temper ature. The serum was decanted, centrifuged at $2500 \times \mathrm{g}$ and preserved at $-18{ }^{\circ} \mathrm{C}$ until analysis.

Heparinised plasma from Holstein cows in early lactation (Group 5) was also assayed.

\section{Statistical analyses}

Single-factor, two-way and two-factor-split-plot analysis of variance (ANOVA) were employed to analyse the results for the groups of cattle where appropriate, including Bartlett's test for non-homogeneity of variance.

\section{Results}

\section{IGFBP patterns}

The ligand blots (Fig. 1) showed significant differences in serum IGFBP patterns between newborn and 12-month-old cattle. At 7 days and 6 months old two of the calves exhibited predominantly $34 \mathrm{kD}$ IGFBP and to a lesser extent $40-45 \mathrm{kD}$ and $24 \mathrm{kD}$ IGFBPs. Sera of both the male and female 12-month-old animals contained predominantly $40-45 \mathrm{kD}$ IGFBP but the $34 \mathrm{kD}$ band markedly decreased in intensity only in the bull. Samples from the periparturient cow were characterised by very intensive $34 \mathrm{kD}$ bands and faint $40-45 \mathrm{kD}$ and $24 \mathrm{kD}$ bands. A faint IGFBP band (possibly a doublet) with a molecular mass around $30 \mathrm{kD}$ appeared in both prepartal and postpartal sera. The electrophoretic pos itions of the $40-45 \mathrm{kD}, 34 \mathrm{kD}, 30 \mathrm{kD}$ and $24 \mathrm{kD}$ bands, which bound the tracer IGF-I, would be compatible with the sizes of IGFBP-3, $-2,-1$ and -4 respectively (McGuire et al., 1992). 


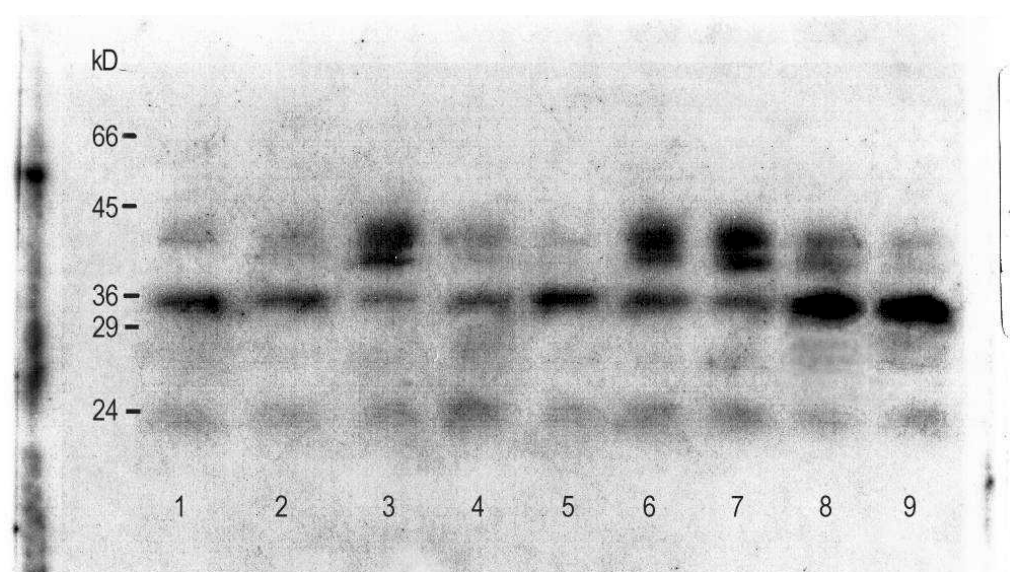

Fig. 1. Autoradiographic patterns of serum IGFBPs after SDS-PAGE and ligand blotting with ${ }^{125} \mathrm{I}-$ IGF-I. Samples in lanes 1-3 were from a male Limousine calf aged 7 days, 6 and 12 months, in lanes 4-5 from a female calf at 7 days and 6 months old, in lanes 6-7 from a female calf at 6 and 12 months old and in lanes 8-9 from a Holstein cow 5 days before and 1 day after calving, respectively

\section{Assay validation}

Molecular sieve chromatography of bull serum at a low $\mathrm{pH}$ separated the IGF ligands from the IGFBPs. A total of $90 \%$ of the IGF-I in the original serum sample was detected in the expected volume of eluate. Dilution curves of these fractions were parallel to reference IGF-I preparations. Additional IGF-I i ncreased the result by $102 \% \pm 4 \%(n=7)$ of the expected amount but additional $h$ IGF-II had no effect in the IGF-I assay. However, in the IGF-II assay increasing concentrations of the bovine IGF fraction were not parallel to the standard curve. Since no pure preparation of bovine IGF-II was available for reference, one point $(0.5 \mathrm{ng} /$ tube $)$ on the curve was taken as the human equivalent and the remaining points were adjusted to follow the dilution profile of IGFBP-free bovine IGF fractions. This standard curve (assay range 0.03-1.2 ng/tube) was used for all determinations of IGF-II in extracts of bovine serum.

When fractions containing the IGFBPs were assayed in the absence of cold ligand, they bound to the tracer, were not sedimented by the precipitation system and therefore appeared as artefact IGF. Values apparently increased by similar amounts in both tests as added IGFBP was increased, indicating that a rival competitive binding system may operate with reversed roles for the tracer and reagent antibodies. In the IGF-I assay the inclusion of h-IGF-II in the inc ubation mixture in physiological amounts $(0.5 \mathrm{ng} /$ tube $)$ completely suppressed the spurious results. IGF-I alone suppressed equivalent amounts of IGFBP completely $(101 \pm 10 \%$ of the expected results) but only partially when IGFBP was in apparent excess. For example, when IGF-I $(0.42 \mathrm{ng})$ was included with IGFBP, which had given a false value of $1 \mathrm{ng} /$ tube, the new result was $0.7 \mathrm{ng}$ or 
$167 \%$ of the expected amount of IGF-I, whereas with $0.5 \mathrm{ng}$ IGF-II/tube the result was $0.03 \mathrm{ng}$, which was below the first standard. Added ligand (IGF-II) b ehaved similarly in the IGF-II assay $(107 \pm 7 \%$ of expected values; $n=6)$ when the amounts added were greater or similar to the false results but inflated values when the IGFBPs remained in excess. However, adding contraligand (IGF-I) only partially suppressed the spurious results.

Having established the effects of separated bovine IGFBPs on the test $r$ esults, the effects of spiking extracts of serum and plasma from different categ ories of cattle with ligand and contraligand was investigated (Table 1). The e xtracts originally provided $0.1-1.1 \mathrm{ng}$ IGF-I and $0.15-0.86 \mathrm{ng}$ IGF-II per tube. Since adding contraligand did not decrease the results obtained, while added $1 \mathrm{i}$ gand increased them by the expected amount within experimental error, it was concluded that there was no significant interference by IGFBPs carried through the extraction procedure.

\section{Table 1}

Effect of adding additional IGF-I and IGF-II to the incubation medium during IGF assays [Mean (SEM)]

\begin{tabular}{lcccc}
\hline \multicolumn{1}{c}{ Category } & No. & $\begin{array}{c}\text { Expected increment } \\
\text { with ligand }(\%)\end{array}$ & No. & $\begin{array}{c}\text { Expected value } \\
\text { with contraligand } \\
(\%)\end{array}$ \\
\hline IGF-I assay & & & & $102.9(6.6)$ \\
Newborn calf serum & 6 & $94.6(9.3)$ & 6 & $99.9(8.3)$ \\
Lactating cow plasma & 6 & $101.9(8.0)$ & 6 & $100.1(6.1)$ \\
\hline IGF-II assay & & & & - \\
Newborn calf serum & 4 & $96.5(7.1)$ & 2 & $98.3(7.9)$ \\
Newborn calf serum & 4 & $86.5(4.6)$ & 3 & $92.2(3.4)$ \\
7-day-old calf serum & 3 & $96.9(7.9)$ & 2 & - \\
4-month-old calf serum & 5 & $88.7(4.8)$ & 3 & - \\
6-month-old calf serum & 3 & $87.4(8.8)$ & & \\
Peripartal cow serum & 4 & $106.5(5.8)$ & & \\
Lactating cow plasma & 4 & $86.8(7.1)$ & & \\
\end{tabular}

*Incubation mixture spiked with bovine IGF fraction

The relation between obtained and expected values for IGF-II after pr ogressive dilution of serum extracts from several calves followed the diagonal as for the bovine IGF column fractions (Fig. 2).

IGF-I determined again in representative beef cattle sera containing a wide range of IGF-I concentrations $(10-80 \mathrm{nmol} / \mathrm{l})$ after about three years storage at $-18{ }^{\circ} \mathrm{C}$ showed excellent agreement $(\mathrm{Y}=0.96 \mathrm{X}-0.15 ; \mathrm{r}=0.999)$. 


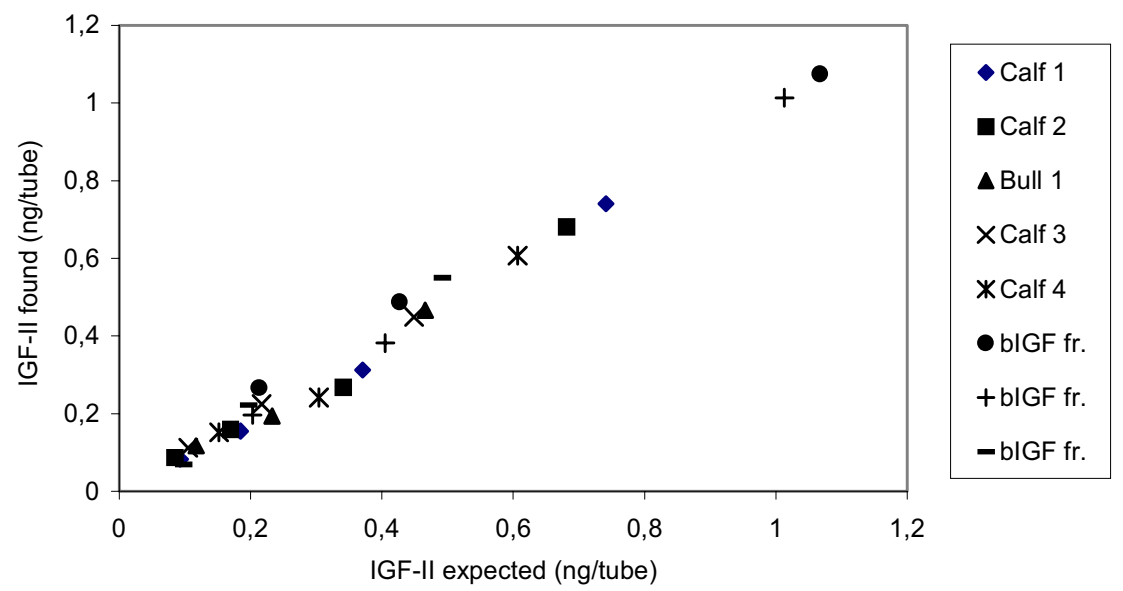

Fig 2. Relation between obtained and expected values for IGF-II after serial dilution of extracts of cattle serum (Calves 1 and 2 - newborn; Calf 3 at 6 months old; Calf 4 at 7 days old) and bovine IGF fractions separated by molecular sieve chromatography in $1 \mathrm{M}$ acetic acid

\section{Serum IGF concentrations}

Mean IGF-I concentrations in female calves ranged from 8.8 to $20.5 \mathrm{nmol} / \mathrm{l}$, tending to be greater in the suckled beef calves than in the dairy calves (Table 2). Lower values $(5.1-10.3 \mathrm{nmol} / \mathrm{l})$ were found in periparturient cows. Highly significant age-related increases were noted in male calves. Very large differences between individual animals were e ncountered at 6 months old.

Compared with the 10-fold difference in mean values for IGF-I found between young beef bulls and periparturient dairy cows, serum IGF-II levels varied within narrow limits. Thus, the greatest mean value found in one group of postpartal dairy cows was just over double the lowest mean value recorded for the group of 12-month-old male beef cattle. Within the groups of cattle a statist ically significant difference was detected between Holstein-Friesian calves at 1 day and 4 months of age.

Since IGF-I concentrations increased with age in male calves without an accompanying decline in IGF-II concentrations, there was a significant increase in overall IGF concentrations as well (Table 2). In a similar way, the decline in IGF-II concentrations in Holstein-Friesian calves between 1 day and 4 months of age led to significant decreases in the sum as well as the IGF-II/IGF-I molar $\mathrm{r}$ atio. Moreover, for the dairy cows, the slight decrease in IGF-I and increase in IGF-II concentrations after calving caused a statistically significant difference in their molar ratio to emerge. 
NIKOLIĆ et al

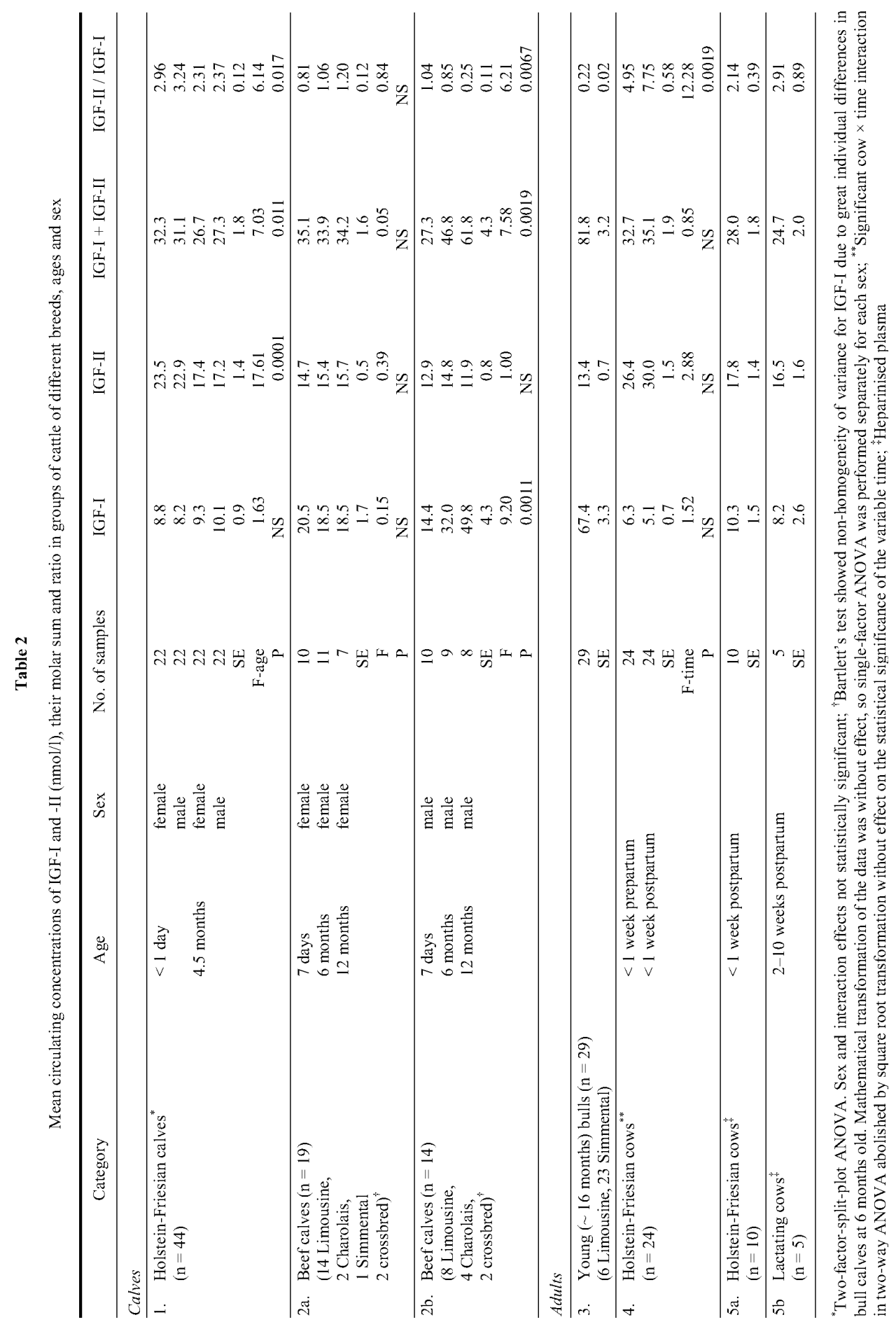

Acta Veterinaria Hungarica 49, 2001 


\section{Discussion}

Our results comply with and extend those obtained by other authors whose investigations were usually confined to particular age categories or breeds of cattle. When methodological problems were discussed, the difficulties encountered and solutions found were comparable with ours. Thus, Lee and Henricks (1990) described 'false' displacement curves with IGFBPs but obtained satisfactory co mparative values for IGF-I by acid-ethanol extraction of sera. Vega et al. (1991) reported $85 \%$ and $88 \%$ recoveries for IGF-I and -II, respectively when known amounts were added to samples before acid-ethanol extraction. One eth anolacetone-acetic acid extraction procedure led to overestimation of low concentr ations and underestimation of high concentrations of IGF-I (73\%-115\%; Gutiérrez et al., 1997) but no such relationship could be deduced for our IGF-I assay. Moreover, since a similar tendency in our IGF-II assay was relatively weak, values obtained were taken as measured and represent h-IGF-II equiv alents.

Mean serum concentrations for IGF-I were lowest in puerperal cows and highest in bulls at slaughter, whereas mean values for IGF-II were lowest in 12month-old bull calves and highest in the cows. The predominance of the putative IGFBP-3 doublet in postpubertal calf serum and the great intensity of the $34 \mathrm{kD}$ band (putative IGFBP-2; Fig. 1) in puerperal cow serum confirm the positive or negative associations observed between IGF-I and IGFBP-3 or IGFBP-2 levels, respectively (Renaville et al., 1993, 1996).

The difference between the sexes found for IGF-I levels in 6- and 12month-old calves was greater than that observed for Holstein calves kept under similar conditions (Kerr et al., 1991) and similar to that recorded for Angus beef cattle (Bishop et al., 1989). According to Breier et al. (1988), the age-dependent prepubertal rise in serum IGF-I in male calves commences with the appearance of functional somatotrophic receptors in the liver. It is independent of nutritional factors and testosterone status (Renaville et al., 1996). Different timing of these changes may have been responsible for the wide range of IGF-I concentrations in our male calves at 6 months old.

In general, the values obtained for IGF-I in growing cattle were similar to those reported by other authors (Bishop et al., 1989; McShane et al., 1989; R enaville et al., 1993). Concerning IGF-II, Holland et al. (1997) reported mean s erum concentrations of $42.8 \mathrm{nmol} / 1$ in crossbred beef fetuses at term which was nearly fivefold higher than the IGF-I levels. Mean IGF-II levels in our dairy calves ( $<1$ day old) were just twofold higher than IGF-I concentrations (Table 2). Our values for puerperal Holstein cows also confirmed those of others (Davis et al., 1987; Vega et al., 1991; Vicini et al., 1991). Higher concentrations were o bserved in Brahman heifers and mid-lactation cows (Hill et al., 1999; McGuire et al., 1995). This report is the first study of both growth factors in beef and dairy cattle of different ages and sexes. 


\section{Acknowledgements}

The co-author from Hungary thanks the Ministry of Education (project number: FKFP-647) and the Hungarian Scientific Research Fund (project number: OTKA T/025 784) for the partial financial support of this study.

\section{References}

Bang, P. (1995): Valid measurements of total IGF concentrations in biological fluids. Recommendations from the $3^{\text {rd }}$ International Symposium on Insulin-like Growth Factors. Endocrinology 136, 816-817.

Bishop, M. D., Simmen, R. C. M., Simmen, F. A. and Davis, M. E. (1989): The relationship of insulin-like growth factor-I with post-weaning performance in Angus beef cattle. J. Anim. Sci. 67, 2872-2880.

Breier, B. H., Gallaher, B. W. and Gluckman, P. D. (1991): Radioimmunoassay for insulin-like growth factor-I: solutions to some potential problems and pitfalls. J. Endocrinol. 128, 347-357.

Breier, B. H., Gluckman, P. D. and Bass, J. J. (1988): Plasma concentrations of insulin-like growth factor-I and insulin in the infant calf: ontogeny and influence of altered nutrition. J. Endocrinol. 119, 43-50.

Daughaday, W. H., Parker, K. A., Borowsky, S., Trivedi, B. and Kapadia, M. (1982): Measurement of somatomedin-related peptides in fetal, neonatal and maternal rat serum by insulin-like growth factor (IGF)-I radioimmunoassay, IGF-II radioreceptor assay (RRA) and multiplication stimulating activity RRA after acid-ethanol extraction. Endocrinol. 110, 575-581.

Davis, S. R., Gluckman, P. D., Hart, I. C. and Henderson, H. V. (1987): Effects of injecting growth hormone or thyroxine on milk production and blood plasma concentrations of insulin-like growth factors I and II in dairy cows. J. Endocrinol. 114, 17-24.

Elsasser, T. H., Rumsey, T. S. and Hammond, A. C. (1989): Influence of diet on basal and growth hormone stimulated plasma concentrations of IGF-I in beef cattle. J. Anim. Sci. 67, 128-141

Groenewegen, P. P., McBride, B. W., Burton, J. H. and Elsasser, T. H. (1990): Effect of bovine somatotropin on the growth rate, hormone profiles and carcass composition of Holstein bull calves. Dom. Anim. Endocrinol. 7, 43-54.

Gutiérrez, C. G., Campbell, B. K., Armstrong, D. G. and Webb, R. (1997): Insulin-like growth factor-I (IGF-I) production by bovine granulosa cells in vitro and peripheral IGF-I measurement in cattle serum: an evaluation of IGF-binding protein extraction protocols. J. Endocrinol. 153, 231-240.

Hill, R. A., Hunter, R. A., Lindsay, D. B. and Owens, P. C. (1999): Action of long(R $\left.{ }^{3}\right)$-insulin-like growth factor-1 on protein metabolism in beef heifers. Dom. Anim. Endocrinol. 16, 219-229.

Holland, M. D., Hossner, K. L., Williams, S. E., Wallace, C. R., Niswender, G. D. and Odde, K. G. (1997): Serum concentrations of insulin-like growth factors and placental lactogen during gestation in cattle. I Fetal profiles. Dom. Anim. Endocrinol. 14, 231-239.

Hossenlopp, P., Seurin, D., Segovia-Quinson, B., Hardouin, S. and Binoux, M. (1986): Analysis of serum insulin-like growth factor binding proteins using Western blotting: use of the method for titration of the binding proteins and competitive binding studies. Anal. Biochem. 154, 138-143.

Hossner, K. L., McCusker, R. H. and Dodson, M. V. (1997): Insulin-like growth factors and their binding proteins in domestic animals. Anim. Sci. 64, 1-15.

Kerr, D. E., Laarveld, B., Fehr, M. I. and Manns, J. G. (1991): Profiles of serum IGF-I concentrations in calves from birth to eighteen months of age and in cows throughout the lactation cycle. Can. J. Anim. Sci. 71, 695-705. 
Lee, C. Y. and Henricks, D. M. (1990): Comparison of various acidic treatments of bovine serum on insulin-like growth factor-I immunoreactivity and binding activity. J. Endocrinol. 127, $139-148$.

McGuire, M. A., Dwyer, D. A., Harrell, R. J. and Bauman, D. E. (1995): Insulin regulates circulating insulin-like growth factors and some of their binding proteins in lactating cows. Am. J. Physiol. 269, (Endocrinol. Metab. 32) E723-E730.

McGuire, M. A., Vicini, J. L., Bauman, D. E. and Veenhuizen, J. J. (1992): Insulin-like growth factors and binding proteins in ruminants and their nutritional regulation. J. Anim. Sci. 70, 2901-2910.

McShane, T. M., Schillo, K. K., Estienne, M. J., Boling, J. A., Bradley, N. W. and Hall, J. B. (1989): Effects of recombinant DNA-derived somatotropin and dietary energy intake on development of beef heifers: II concentrations of hormones and metabolites in blood sera. J. Anim. Sci. 67, 2237-2244.

Nikolić, J. A., Nedić, O., Gavrović, M., Stojanović, D. and Živković, B. (1998a): Different serum insulin-like growth factor-I (IGF-I) binding characteristics accompany reduced growth associated with low thyroid hormone and/or low total IGF-I status in young pigs. Acta Vet. Beograd. 48, 3-18.

Nikolić, J. A., Nedić, O. and Masnikosa, R. (1998b): Determination of insulin-like growth factor-II in human serum. J. Serb. Chem. Soc. 63, 805-815.

Nikolić, J. A., Ratković, M. and Nedić, O. (1996): Determination of insulin-like growth factor-I by radioimmunoassay. J. Serb. Chem. Soc. 61, 1149-1157.

Renaville, R., Devolder, A., Massart, S., Sneyers, M., Burny, A. and Portetelle, D. (1993): Changes in the hypophyseal-gonadal axis during the onset of puberty in young bulls. J. Reprod. Fert. 99, 443-449.

Renaville, R., Massart, S., Sneyers, M., Falaki, M., Gengler, N., Burny, A. and Portetelle, D. (1996): Dissociation of increases in plasma insulin-like growth factor I and testosterone during the onset of puberty in bulls. J. Reprod. Fert. 106, 79-86.

Simmen, F. A. (1991): Expression of the insulin-like growth factor-I gene and its products: complex regulation by tissue specific and hormonal factors. Dom. Anim. Endocrinol. 8, 165-178.

Skaar, T. C., Vega, J. R., Pyke, S. N. and Baumrucker, C. R. (1991): Changes in insulin-like growth factor binding proteins in bovine mammary secretions associated with pregnancy and parturition. J. Endocrinol. 131, 127-133.

Stewart, C. E. H. and Rotwein, P. (1996): Growth, differentiation and survival: multiple physiological functions for insulin-like growth factors. Phys. Rev. 76, 1005-1026.

Vega, J. R., Gibson, C. A., Skaar, T. C., Hadsell, D. L. and Baumrucker, C. R. (1991): Insulin-like growth factor (IGF)-I and -II binding proteins in serum and mammary secretions during the dry period and early lactation in dairy cows. J. Anim. Sci. 69, 2538-2547.

Vicini, J. L., Buonomo, F. C., Veenhuizen, J. J., Miller, M. A., Clemmons, D. R. and Collier, R. J. (1991): Nutrient balance and stage of lactation affect responses of insulin, insulin-like growth factors I and II and insulin-like growth factor binding protein 2 to somatotropin administration in dairy cows. J. Nutr. 121, 1656-1664. 